\title{
FATHERING ADVERSITY MANAGEMENT
}

\author{
Husin \\ Dosen, Sekolah Tinggi Ilmu Al-Qur'an (STIQ) Amuntai, \\ Kalimantan Selatan \\ Email : husin@stiq-amuntai.ac.id
}

\begin{abstract}
Abstrak
Peran ayah dalam sebuah keluarga sangatlah penting dalam membentuk kepribadian anak yang mandiri dan bertanggung jawab. Perannya tidak hanya sebagai sosok yang kuat sebagai penopang perekonomian keluarga, akan tetapi juga pembentuk karakter pantang menyerah (Adversity Quotient) yang sangat berguna bagi masa depan anak. Kajian tentang mengembalikan posisi ayah kepada yang penulis maksudkan sangatlah penting untuk diteliti dalam sebuah kajian tekstual (ayat-ayat Alquāan) dan dalam kontekstual kekinian. Metodologi penelitian yang digunakan bersifat library research dengan mengetengahkan ayat-ayat dialog antara ayah dan anak dalam Alqurān, serta menggali pendapat dari tokoh-tokoh pendidikan anak yang kemudian proses content analysis menjadi pilihan peneliti ketika menganalisisnya. Hasil penelitian ini mengemukakan bahwa ada 14 dialog antara ayah dan anak dalam Alqurān, sehingga menjadi sebuah pelajaran besar bagi seorang ayah bagaimana menempatkan posisinya dalam sebuah keluarga yang juga harus bisa menjadi imam, teman, pendidik dan mengajarkan kepada anak bagaimana menjadi pribadi yang tangguh, sabar, tidak mudah menyerah yang kemudian penulis sebut dengan FAM (Fathering Adversity Management).
\end{abstract}

Kata Kunci : Pola Asuh, Adversity Quotient, FAM

\section{A. Pendahuluan}

Dewasa ini penting menjadi kajian bersama untuk didiskusikan kembali tentang peran seorang ayah dan ibu dalam keluarga. Kita memang cenderung menempatkan seorang ibu hanya sebagai sosok yang membesarkan anak-anak tanpa disadari bahwa ada peran ayah yang terabaikan. Ada pemahaman yang kuat oleh umat Islam ketika memahami hadits dari Rasulullah saw. Bagaimana seorang anak diwajibkan berbakti kepada ibunya melebihi dari baktinya kepada 
ayahnya. ${ }^{1}$ Dalam beberapa hadits juga mengatakan bahwa surga terletak dibawah telapak kaki ibu. ${ }^{2}$ Akibatnya, kita cenderung fokus kepada sosok ibu yang mempunyai peran dalam keluarga dan melihat sosok ayah hanya sebagai individu, bukan sebagai seorang kepala rumah tangga mempunyai yang peran utama dalam menahkodai bahtera rumah tangga. Selain itu ada anggapan tentang peran ayah yang hanya menempatkan posisi ayah sebagai pelindung finansial keluarga akhirnya menyempitkan makna dari hubungan antara ayah dan anak. Seorang ayah seharusnya bisa memainkan peran lebih penting dari hal itu, tidak hanya sebagai seorang ayah akan tetapi juga sebagai guru, teman berbagi cerita dan pembimbing spiritual bagi anak-anaknya.

Sudut pandang pendidikan Islam terkait dengan pola asuh ayah terhadap anak-anaknya bisa kita lihat dari sosok Nabi Ya'qūb yang mendidik anak-anaknya. Secara utuh bagaimana beliau mendidik anakanaknya dapat kita lihat dalam Alqurān surah ke-12 yang bernama surah Yūsuf. Prinsif pengasuhan anak yang berpangkal dari rasa kasih sayang, tidak membedakan antara anak yang satu dengan yang lainnya, mengajarkan keimanan, kesabaran, tidak cepat berputus asa ketika

\footnotetext{
${ }^{1}$ Lihat HR. Bukhari no. 5971 dan Muslim no. 2548. Imam Al-Qurthubi menjelaskan, "Hadits tersebut menunjukkan bahwa kecintaan dan kasih sayang terhadap seorang ibu, harus tiga kali lipat besarnya dibandingkan terhadap seorang ayah. Nabi shalallaahu 'alaihi wasallam menyebutkan kata ibu sebanyak tiga kali, sementara kata ayah hanya satu kali. Bila hal itu sudah kita mengerti, realitas lain bisa menguatkan pengertian tersebut. Karena kesulitan dalammenghadapi masa hamil, kesulitan ketikamelahirkan, dan kesulitan pada saat menyusui dan merawat anak, hanya dialami oleh seorang ibu. Ketiga bentuk kehormatan itu hanya dimiliki oleh seorang ibu, seorang ayah tidak memilikinya. (Lihat Tafsir Al-Qurthubi X : 239. alQadhi Iyadh menyatakan bahwa ibu memiliki keutamaan yang lebih besar dibandingkan ayah)

${ }^{2}$ Diriwayatkan oleh an-Nasai, jilid 2, h. 54, dan yang lainnya seperti athThabrani jilid 1, h. 225, no. 2. Sanadnya Hasan insya Allah. Dishahihkan oleh alHakim, jilid 4, h. 151, dan disetujui oleh adz-Dzahabi dan juga oleh al-Mundziri, jilid 3, h. 214." (as-Silsilah adh-Dha'ifah wa al-Maudhu' ah, pada penjelasan hadits no. 593.)
}

Jurnal Ilmiah Al QALAM, Vol. 12, No. 2, Juli-Desember 2018 
menghadapi suatu permasalahan adalah bagian dari pola asuh ayah yang dapat kita gali dalam surah tersebut. Selain itu, Nabi Iberāhim, Nabi Luth, Nabi Daud, Luqmān al-Hakim adalah sosok ayah yang diabadikan di dalam Alquran yang juga dapat dijadikan sebagai teladan.

\section{B. Metode Penelitian}

Artikel ini mengangkat kajian tentang Adversity Quotient dan konsep pola asuh ayah dalam Alqurān sehingga data primer yang akan menjadi kajian peneliti adalah teori tentang Adversity Quotient oleh Paul G. Stoltz dan ayat-ayat dalam Alqurān yang menceritakan latar dialog antara ayah dan anak (termasuk didalamnya kitab tafsir sebagai penjelas ayat-ayat tersebut). Akan tetapi nantinya peneliti juga menggunakan data sekunder yang bisa menginterpretasikan data primer seperti perkataan para ulama, buku-buku yang berkaitan dengan parenting anak, tokoh-tokoh pendidikan anak maupun buku-buku psikologi yang bisa dijadikan sebagai penjelas makna dalam Alqurān.

Untuk mengumpulkan data, peneliti menggunakan penelitian kepustakaan (library research) yaitu dengan cara menelaah referensi atau literatur yang terkait dengan Adversity Quotient dan pola asuh ayah dalam Alqurān, baik yang berbahasa asing maupun yang berbahasa Indonesia.

Karena penelitian ini nantinya menyangkut kajian terhadap ayatayat Alqurān, maka bahan primer dari penelitian ini adalah kitab suci Alquān. Sedangkan alat bantu untuk memahami ayat-ayat tersebut maka peneliti menggunakan beberapa buah kitab tafsir yang sudah sering digunakan di kalangan masyarakat maupun akademis muslim. Kitab-kitab tafsir ini nantinya digunakan untuk memberikan ulasan 
makna tekstual, maupun makna kontekstual terhadap ayat-ayat yang mengandung dialog antara ayah dan anak di dalam Alqurān.

Agar data yang diperoleh nantinya dapat dijadikan sebagai bahasan yang akurat, maka peneliti dalam menganalisis data yang dimaksud dengan menggunakan metode pengolahan data dan analisis data yang bersifat deskriptif dengan cara berfikir deduktif komparatif juga menggunakan content analysis.

\section{Pola Asuh Ayah Dalam Berbagai Pandangan}

Keluarga $^{3}$ adalah bentuk kecil dari sebuah komunitas sosial di masyarakat. Dari kumpulan keluarga tersebut akan terbentuk beragam bentuk kelompok masyarakat yang mempunyai pola kebiasaan, pola sosial keagamaan, pola perekonomian hingga adat dan kebiasaan setempat. Gambaran hal tersebut dapat dilihat pada Q.S. Al-Isrā / 17:6 sebagai berikut :

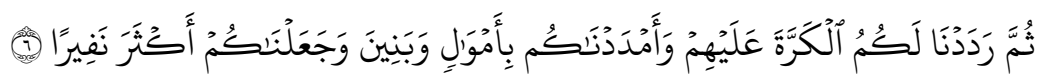
Artinya :Kemudian Kami berikan kepadamu giliran untuk mengalahkan mereka kembali dan Kami membantumu dengan harta kekayaan dan anak-anak dan Kami jadikan kamu kelompok yang lebih besar.

Keluarga juga dimaknai sebagai sekelompok orang yang terdiri dari orang tua, yaitu seorang laki-laki yang lazim disebut dengan panggilan ayah, seorang perempuan yang biasanya disebut dengan

\footnotetext{
${ }^{3}$ Menurut UU Nomor 35 tahun 2014 tentang perlindungan anak pasal 1 ayat 3 menjelaskan bahwa keluarga adalah unit terkecil dalam masyarakat yang terdiri atas suami istri, atau suami istri dan anaknya, atau ayah dan anaknya, atau ibu dan anaknya, atau keluarga sedarah dalam garis lurus ke atas atau ke bawah sampai dengan derajat ketiga. Diakses melalui http://www.kpai.go.id/files/2013/09/uu-nomor-35-tahun-2014tentang-perubahan-uu-pa.pdf pada tanggal 13 Februari 2017. 282.

${ }^{4}$ Kementerian Agama, Al-Quran Tikrar (Bandung: Sygma Creative, 2014), h.
}

Jurnal Ilmiah Al QALAM, Vol. 12, No. 2, Juli-Desember 2018 
panggilan ibu, dan hasil keturunan dari keduanya yang disebut dengan anak.

Hati dan perasaan kedua orang tua sebenarnya secara fitrah mencintai anak dan akan tumbuh perasaan-perasaan kejiwaan dan cinta kasih seorang ayah untuk menjaganya, menyayanginya, dan merindukannya serta memperhatikan urusannya. ${ }^{5}$ Tidak aneh jika Alquāan menggambarkan perasaan kebapakan dengan penggambaran yang indah. Allah memperumpamakan anak sebagai hiasan dunia ${ }^{6}$, di lain ayat diibaratkan sebagai sebuah nikmat agung yang harus disyukuri $^{7}$, dan juga diperumpamakan sebagai penyejuk mata jika mereka berjalan pada jalannya orang-orang yang bertaqwa. ${ }^{8}$

Pola pendidikan tradisional menempatkan laki-laki dan perempuan dalam wadah yang berbeda. ${ }^{9}$ Pada masa penjajahan dan pra kemerdekaan, pendidikan untuk anak perempuan tidak terlalu menjadi prioritas bagi orang tua dibandingkan dengan anak laki-laki. Anak perempuan biasanya lebih ditekankan bagaimana nanti perannya sebagai seorang istri dan seorang ibu. Sehingga pendidikan yang diajarkan kepada anak perempuan hanya seputar dapur, kasur dan sumur.

Tidak demikian halnya dengan anak laki-laki. Orang tua yang mempunyai anak laki-laki cenderung memperhatikan bagaimana

\footnotetext{
${ }^{5}$ Abdullah Nashih 'Ulwan, Pendidikan Anak Dalam Islam, terj. Arif Rahman Hakim (Jawa Tengah: Insan Kamil Solo, 2017), h. 19.

${ }^{6}$ Lihat Q.S Al-Kahfi / 18:46.

${ }^{7}$ Lihat Q.S. Al-Isrā / 17:6.

${ }^{8}$ Lihat Q.S Al-Furqān / 25:74.

${ }^{9}$ Kebudayaah telah menentukan peran-peran tertentu bagi seorang suami (ayah) dan istri (ibu). Pandangan tradisional melihat peran ayah tugas utamanya sebagai kepala keluarga dan sebagai pencari nafkah, disamping itu ia juga bertanggung jawab terhadap pendidikan anak-anaknya. Seorang istri diharapkan dapat mengurus rumah tangganya dan merawat suami serta anak-anaknya dengan baik, disamping menjadi pendamping bagi suaminya. Lubis Salam, Menuju Keluarga Sakinah Mawaddah Wa Rahman (Surabaya: Terbit Terang, tt), h. 76.
}

Jurnal Ilmiah Al QALAM, Vol. 12, No. 2, Juli-Desember 2018 
kualitas pendidikan mereka. Hal ini sepertinya wajar karena seorang laki-laki dipandang sebagai kepala rumah tangga yang nantinya berperan besar dalam menyokong perekonomian keluarga. Di pundaknyalah segala hal terkait dengan keperluan sandang, pangan dan papan dibebankan.

Menurut Kamrani Buseri bahwa pola pengasuhan seperti itu sebenarnya tidak bisa disalahkan, karena kalau ditinjau dari segi sosiologis seseorang akan menjadi pemimpin karena ada kelebihan yang dimilikinya melebihi apa yang dipunyai orang lain. ${ }^{10}$ Begitu juga dengan ayah yang menjadi pemimpin dalam keluarga karena telah dianugerahkan oleh Allah beberapa kelebihan jika dibandingkan dengan anggota keluarga yang lain (istri dan anaknya). ${ }^{11}$ Zamakhsyari $^{12}$ menjelaskan bahwa kelebihan yang diberikan kepada seorang laki-laki (ayah) sebagai pemimpin dalam keluarga bukan atas dasar kebiasaan, kehormatan, maupun paksaan akan tetapi lebih didasari atas daya pikir,

\footnotetext{
${ }^{10}$ Kamerani Buseri, Pendidikan Keluarga Dalam Islam dan Gagasan Implementasinya (Banjarmasin: Lantin G, 2010), h. 93.

${ }^{11}$ Lihat Q.S. An-Nisa / 4:34.

${ }^{12}$ Nama asli beliau adalah Abu al-Qāsim Mahmūd ibn Umar al-Zamakhsyarì yang dikenal dengan sebutan Zamakhsyari. Beliau dilahirkan di Zamakhsyar tanggal 18 Maret $1075 \mathrm{M}$ dan wafat pada 12 Juni $1144 \mathrm{M}$ akan tetapi menjalani sebagian besar hidupnya di Bukhara, Samarkand dan Baghdad. Beliau adalah seorang cendikiawan muslim abad pertengahan asal Persia yang beraliran Muktazilah. Karya beliau yang cukup terkenal adalah Tafsī Kasysyaf. Al-Kasysyaf karya Zamakhsyari memang tergolong salah satu kitab tafsir yang cukup populer. Sedikitnya, ada dua hal yang menyebabkan kitab tersebut termasyhur. Pertama adalah melimpahnya analisis bahasa dalam penafsiran sedang kedua adalah afiliasi penulisnya dengan madzhab Muktazilah. Secara umum Al-Kasysyaf dianggap sebagai tafsir tahlili yang bercorak ra'yi karena kuatnya analisis logika didalamnya.
}

Jurnal Ilmiah Al QALAM, Vol. 12, No. 2, Juli-Desember 2018 
keteguhan hati juga kemauan yang keras. Disamping itu juga adanya keharusan memberikan mahar dan perbelanjaan anak istri. ${ }^{13}$

Dewasa ini penting menjadi kajian bersama untuk didiskusikan kembali tentang peran seorang ayah dan ibu dalam keluarga. Pola pengasuhan anak sekarang cenderung menempatkan seorang ibu hanya sebagai sosok yang membesarkan anak-anak tanpa disadari bahwa ada peran ayah yang terabaikan. Ada pemahaman yang kuat oleh umat Islam ketika memahami hadits dari Rasulullah saw. Bagaimana seorang anak diwajibkan berbakti kepada ibunya melebihi dari baktinya kepada ayahnya. ${ }^{14}$ Beberapa hadits juga mengatakan bahwa surga terletak dibawah telapak kaki ibu. ${ }^{15}$ Akibatnya, ada kecenderungan fokus kepada sosok ibu yang mempunyai peran dalam keluarga dan melihat sosok ayah hanya sebagai individu, bukan sebagai seorang kepala keluarga yang mempunyai peran utama dalam menahkodai bahtera rumah tangga. Selain itu ada anggapan tentang peran ayah yang hanya menempatkan posisi ayah sebagai pelindung finansial keluarga akhirnya menyempitkan makna dari hubungan antara ayah dan anak. Seorang ayah seharusnya

\footnotetext{
${ }^{13}$ Abu al-Qāsim Mahmūd ibn Umar al-Zamakhsyarī, Al-Kasysyaf 'an Haqa'iq at-Tanzīl wa 'Uyūn al-Aqāwil Fì Wujūh at-Ta'wìli, juz 1 (Mesir: Musthafa al-Bāb alHalabȳ wa Aulāduh, tt), h. 523-524.

${ }^{14}$ Lihat HR. Bukhari no. 5971 dan Muslim no. 2548. Imam Al-Qurthubi menjelaskan, "Hadits tersebut menunjukkan bahwa kecintaan dan kasih sayang terhadap seorang ibu, harus tiga kali lipat besarnya dibandingkan terhadap seorang ayah. Nabi shalallaahu 'alaihi wasallam menyebutkan kata ibu sebanyak tiga kali, sementara kata ayah hanya satu kali. Bila hal itu sudah dimengerti, realitas lain bisa menguatkan pengertian tersebut. Karena kesulitan dalam menghadapi masa hamil, kesulitan ketika melahirkan, dan kesulitan pada saat menyusui dan merawat anak, hanya dialami oleh seorang ibu. Ketiga bentuk kehormatan itu hanya dimiliki oleh seorang ibu, seorang ayah tidak memilikinya. (Lihat Tafsir Al-Qurthubi X : 239. alQadhi Iyadh menyatakan bahwa ibu memiliki keutamaan yang lebih besar dibandingkan ayah)

${ }^{15}$ Diriwayatkan oleh Al-Khathīb dalam Akhlāq ar-Rāwìi(2/231, no. 1702) dan Al-Qudlā'i (1/102, no. 119) dari Anas Ibn Mālik.
}

Jurnal Ilmiah Al QALAM, Vol. 12, No. 2, Juli-Desember 2018 
bisa memainkan peran lebih penting dari hal itu, tidak hanya sebagai seorang ayah akan tetapi juga sebagai guru, teman berbagi cerita dan pembimbing spiritual bagi anak-anaknya. ${ }^{16}$

Sebuah seminar parenting yang diadakan di Sekolah Has Darul Ilmi Bandung yang mengangkat tema The Power of Superdad dengan pembicara Tjatur Hendry Juliadi mengemukakan bahwa paling tidak ada 17 dialog antara orang tua dan anaknya dalam Alqurān. 14 ( empat belas

\footnotetext{
${ }^{16}$ Diceritakan bahwa ayah dari Imam Mālik bin Anas ditengah-tengah pembicaraan perihal kesehariannya dengan keluarganya, ia tidak pernah lupa menuturkan pula kepada anak-anaknya dan kepada istrinya riwayat-riwayat Hadits Nabi saw. yang dicatatnya dengan baik dalam ingatan yang dituturkan kepadanya oleh ayahnya, yang diperoleh dari kakeknya, seorang shahabat Rasulullah saw. Mereka pun dengan sekasama mendengarkan dengan penuh perhatian, lalu menghafalkannya dalam ingatan. Muchlis M. Hanafi dkk, Biografi Lima Imam Madzhab Imam Mālik Penapak Atsār dan Tradisi Ahli Madinah Pendiri Madzhab Maliki, (Tangerang: Lentera Hati, 2013), h. 4. Bagi ayah yang hidup dalam garis kemiskinan atau dengan penghasilan rendah, bisa jadi ada tantangan terutama jika mereka memegang pandangan tradisional mengenai peran ayah sebagai pencari nafkah. Lihat Jenifer Shadik, Fathering Child Maltreatment : A Grounded Theory Study, (Richmond : Virginia Commonwealth University, 2014), h. 39-40. Sejalan dengan hal tersebut, Jeniffer Shadik mencatat bahwa ada beberapa fase perubahan dalam menempatkan peran dan tanggung jawan ayah dalam keluarga. Selama masa penjajahan, ayah dianggap sebagai orang tua utama. Mereka memiliki otoritas penuh dalam hal yang berkaitan dengan anak dan ibunya. Posisi ayah juga dianggap sebagai orang tua utama dari sudut pandang hukum, bahkan mereka memiliki hak asuh anak apabila terjadi perceraian. Selama periode industrialisasi di abad ke-19, peran orang tua didefinisikan ulang. Ayah dianggap sebagai pencari nafkah dan penyedia upah. Sebagian besar, ibu berada di rumah bersama anak-anak mereka dan memiliki tanggung jawab utama terhadap keduanya (anak dan rumah). Pada tahun 1847, sebagian besar pengadilan merasa bahwa ibu paling mampu merawat anak-anaknya dan hak asuh umumnya diberikan kepada ibu. Lihat Jenifer Shadik, Fathering Child Maltreatment ..., h. 3. Para ahli fiqih pun menetapkan bahwa seorang ibu lebih diprioritaskan daripada ayah dalam hal pengasuhan anak. Hal ini dikarenakan seorang ibu mempunyai kemampuan maksimal dalam menjaga dan memperhatikan hal-hal yang diperlukan oleh anak. Seorang ibu mampu mendidik anak dan menjaganya dengan penuh perhatian serta melindunginya dari berbagai macam penyimpangan dan kerusakan. Lihat Syekh Khalid bin Abdurrahman al-'ik, Prophetic Parenting, terj. Dwi dan Aguk (Yogyakarta: Laksana, 2017), h. 133.
}

Jurnal Ilmiah Al QALAM, Vol. 12, No. 2, Juli-Desember 2018 
) diantaranya adalah dialog ayah dengan anaknya ${ }^{17}, 2$ dialog antara ibu dan anaknya ${ }^{18}$, dan sebuah dialog lagi tidak jelas ${ }^{19}$ apakah itu merupakan dialog antara dengan ayah atau dengan ibu. ${ }^{20}$ Ayat-ayat tersebut mengandung pesan yang sangat penting bagaimana peran ayah juga ikut berpartisifasi aktif dalam membesarkan anak-anaknya. Hal ini juga membuka mata orang-orang atas paradigma lama yang memberikan batasan kaku bahwa ayah adalah penanggung jawab finansial dan ibu bertugas mengurus anak-anak. Ayat-ayat tersebut membuktikan bahwa peletakan dasar tauhid dan keimanan adalah tanggung jawab dari seorang ayah. Sebagaimana pada penelitian Agus Setiawan bahwa anak merupakan salah satu bagian dalam keluarga, sehingga secara kodrati tanggung jawab pendidikan tauhid berada di tangan orang tua. ${ }^{21}$

Menurut Putri Maharani yang mengutip dari Gottman, J. \& Declaire, J. dalam bukunya yang berjudul The Heart of Parenting: How to Raise an Emotionally Intelligent Child ${ }^{22}$ menyatakan bahwa para ahli

${ }^{17}$ Lihat Al-Baqarah/2:132-133, Al-An'ām / 6:74, Hūd / 11:42-43, Yūsuf / 12:45, Yūsuf / 12:11-14, Yūsuf / 16-18, Yūsuf / 12:81-87, Yūsuf / 12:94-98, Yūsuf / 99-100, Maryām / 19:41-48, Al-Qashash / 28:26, Luqmān / 31: 13-19, As-Shaffat / 37:102.

${ }^{18}$ Lihat Maryām / 19:23-27, Al-Qashash / 28:11.

${ }^{19}$ Lihat Al-Ahqāf / 46:17.

${ }^{20}$ Pernyataan ini berdasarkan penelusuran peneliti sebenarnya diambil dari hasil tesis Sarah binti Halil Al-Muthairi, "Hiwār al-Abā ma'al Abnā Fil Qurānil Karīm Wa Tathbiqqätuhu at-Tarbawiyah” (Tesis tidak diterbitkan, Universitas Ummul Qura, Mekkah, 2008), h. 87-142.

${ }^{21}$ Agus Setiawan, Konsep Pendidikan Tauhid dalam Keluarga Perspektif Pendidikan Islam, EDUCASIA, Vol. 2 No. 1, 2017, hal. 3

${ }^{22}$ Putri Maharani dan Budi Andayani, "Hubungan Antara Dukungan Sosial Ayah Dengan Penyesuaian Sosial Pada Remaja Laki-Laki “Jurnal Psikologi UGM), vol.xxx no.1 (2003): h. 28. Penelitian yang dilakukan oleh mereka mengungkap berpengaruhnya keterlibatan ayah dalam pembentukan pribadi anak. Absennya ayah dalam pengasuhan anak berkontribusi memunculkan berbagai penyakit masyarakat. Peran ayah amat penting dalam membangun kecerdasan emosional anak. Seorang anak yang dibimbing oleh ayah yang peduli, perhatian, dan menjaga komunikasi, cenderung berkembang menjadi anak yang lebih mandiri, kuat, dan memiliki pengendalian emosi yang lebih baik dibandingkan anak yang tidak memiliki ayah.

Jurnal Ilmiah Al QALAM, Vol. 12, No. 2, Juli-Desember 2018 
psikologi telah lama berpendapat bahwa keterlibatan ayah dalam mengasuh anak itu penting. Ayah akan mempengaruhi anak dengan cara yang berbeda dengan para ibu, terutama di bidang-bidang seperti hubungan anak dengan teman sebaya dan prestasi akademis. Anak yang "miskin" akan peran ayahnya, dalam perkembangannya akan mendapatkan gangguan-gangguan atau ketidakseimbangan, terutama berkaitan dengan peran jenis kelamin terhadap dirinya. Sebaliknya keterlibatan ayah dalam mendampingi tumbuh kembang anak akan bisa membantu remaja untuk meningkatkan rasa percaya diri dalam diri anak dan meningkatkan kemampuan mereka untuk melawan tekanan teman sebaya.

Selanjutnya dalam buku tersebut mengetengahkan penelitian yang dilakukan oleh Robert Blanchard dan Henry Biller yang membandingkan tiga kelompok anak laki-laki. Kelompok pertama adalah kelompok anak yang ayahnya ada dan masuk dalam kehidupan anak, kelompok ke dua adalah anak-anak yang ayahnya tidak ada, dan kelompok ke tiga adalah anak-anak yang ayahnya ada tapi tidak terlibat dalam kehidupan anak. Hasil penelitian ini menunjukkan bahwa prestasi akademik anak kelompok pertama adalah yang paling baik, kelompok ke dua paling buruk, dan kelompok ke tiga berada di tengah. Menurut Putri Maharani, Biller sendiri mengatakan bahwa “...memiliki ayah yang punya kecakapan tidak akan memfasilitasi perkembangan intelektual anak jika ayah tidak secara konsisten masuk dalam kehidupan anak lakilaki atau jika kualitas hubungan ayah dan anak laki-lakinya negatif...."23

\footnotetext{
${ }^{23}$ Putri Maharani dan Budi Andayani, "Hubungan Antara ..., h. 29. Penelitian telah menemukan bahwa nilai keterlibatan ayah ditentukan oleh kualitas interaksi antara ayah dan anak mereka - misalnya, respons seorang ayah untuk keperluan anaknya - bukan jumlah kuantitas waktu ayah yang dihabiskan dengan mereka.
}

Jurnal Ilmiah Al QALAM, Vol. 12, No. 2, Juli-Desember 2018 
Berdasarkan sebuah penelitian yang dilakukan oleh Jeffrey Rosenberg $^{24}$ dan W. Bradford Wilcox ${ }^{25}$ dari U.S. Department of Health and Human Services Administration For Children and Families ${ }^{26}$ menjelaskan bahwa bayi yang ayahnya terlibat langsung dalam merawat, mengasuh dan mengajaknya bermain cenderung memiliki IQ yang lebih tinggi disamping juga memiliki kapasitas linguistik yang lebih baik dibandingkan dengan bayi yang tidak. Pengaruh keterlibatan ayah dalam hal pengasuhan anak juga memiliki dampak yang sangat siginifikan terhadap prestasi akademik anak, remaja bahkan sampai dewasa. Rosenberg dan Bradford juga mengemukakan sejumlah penelitian yang menemukan bahwa ayah yang aktif terlibat dalam mengasuh anak juga akan mempengaruhi keterampilan verbal, fungsi intelektual dan prestasi akademik di kalangan remaja.

Menurut peneliti kenyataannya sekarang banyak orang tua khususnya figur ayah sudah mulai hilang dalam dunia anak. Hal ini dilatar belakangi oleh kondisi ekonomi yang menuntut seorang ayah bekerja lebih ekstra untuk mencukupi keperluan keluarga. Disamping itu, dengan semakin pesatnya perkembangan tekhnologi, membuat ayah dan

William Scott and Amy De La Hunt, The Important Role of Fathers in the Lives of Young Children (st.Louis : Parents as Teachers, 2011) diakses melalui laman https://tanderson.squarespace.com/s/ImportantRoleofFatherstanggal 7 Januari 2018.

${ }^{24}$ Jeffrey Rosenberg adalah penggagas berdirinya Rosenberg Communication, sebuah lembaga yang mengedukasi masyarakat dalam hal hubungan kemasyarakatan. Rosenberg bekerjasama dengan National Fatherhood Initiative dalam hal merancang dan menerapkan strategi untuk mendidik masyarakat terkait dengan isu keterlibatan ayah dalam hal pengasuhan anak.

${ }^{25}$ W. Bradford Wilcox, Ph.D., adalah asisten professor dalam bidang sosiologi di Universitas of Virginia dan seorang anggota dari James Madison Society di Peinceton University. Penelitiannya berfokus pada isu agama, pernikahan dan pola asuh ayah dalam keluarga.

${ }^{26}$ Jeffrey Rosenberg and W. Bradford Wilcox, The Imprortance of Fathers in the Healthy Development of Children, (tt ; tp ; 2006), h.12.

Jurnal Ilmiah Al QALAM, Vol. 12, No. 2, Juli-Desember 2018 
anak tidak lagi mempunyai hubungan yang intens layaknya orang tua dan anak. Pola komunikasi dibatasi dengan penggunaan handphone dan media sosial seperti whatsapp, facebook, instagram dan lain sebagainya. Senada dengan pernyataan Vera Astuti dan Achmad Mujab Syakur yang menegaskan bahwa seorang ayah yang berhasil mencetak anak-anak yang matang secara spiritual, emosional dan intelektual, tanpa melalaikan tanggung jawabnya sebagai orang yang bertanggung jawab dalam hal keuangan keluarga merupakan bentuk pengasuhan yang ideal ${ }^{27}$, tidak hanya dipandang dari sudut Alqurān saja melainkan juga berdasarkan penelitian yang telah disebutkan sebelumnya. ${ }^{28}$

${ }^{27}$ Vera Astuti dan Achmad Mujab Masykur, "Pengalaman Keterlibatan Ayah Dalam Pengasuhan Anak (Studi Kualitatif Fenomenologis), Jurnal Empati Volume 4, no. 2 (2015): h. 66. Pada dasarnya peneliti tidak ingin menghilangkan peran ibu dalam pendidikan anak, karena seorang ibu yang single fighter pun bisa mendidik anak yang hebat. Imam Syafi'I terlahir tanpa sempat merasakan dekapan hangat sang ayah yang meninggal beberapa bulan sebelum kelahirannya karena diserang sakit. Memandang keberhasilan Imam Syafi'I kecil yang kelak menjadi orang hebat dimasa dewasanya, dapat ditarik kesimpulan bahwa sang ibu adalah seorang yang berwawasan luas, pendidik yang baik, dan pejuang yang gigih. Muchlis M. Hanafi dkk, Biografi Lima Imam Madzhab Imam Syāfí'i Sang Penopang Hadits dan Penyusun Ushul Fiqh Pendiri Madzhab Syafi'i, (Tangerang: Lentera Hati, 2013), h. 18. Imam Ahmad bin Hanbal sendiri dilahirkan sebagai anak yatim seperti gurunya Imam Syāfi'i. dia belum pernah melihat bapaknya dan kakeknya. Dia diasuh oleh ibunya dan keluarga bapaknya. Muchlis M. Hanafi dkk, Biografi Lima Imam Madzhab Imam Ahmad Imam Besar dan teladan Bagi Umat Pendiri Madzhab Hanbali, (Tangerang: Lentera Hati, 2013), h. 5. Akan tetapi menurut peneliti melibatkan peran ayah dalam pengasuhan anak juga merupakan suatu hal yang penting untuk diangkat dan dijadikan mindset.

${ }^{28}$ Melalui acara "Wardah Berbagi Inspirasi" di Muslim Fashion Festival 2016, psikolog anak Elly Risman mengatakan bahwa menjadi orang tua adalah tugas yang paling sulit, apalagi jika orang tua tidak memiliki bekal yang cukup untuk mendidik anak. Beliau mengungkapkan hasil riset tesis yang mengungkapkan jika anak kurang kasih sayang ayah, ayah tidak dekat dengan anak, emosi anak akan terganggu. Kalau laki-laki cenderung akan nakal, seks bebas, dan narkoba, sedangkan anak perempuan akan depresi dan melakukan seks bebas. Hubungan emosi anak dengan orang tua harus dekat. "Dibutuhkan attachment antara ayah dan anak, juga ibu dengan anak," katanya. Ia menuturkan, banyak anak yang kurang dekat atau kurang 'lengket' dengan orang tua mereka karena banyak hal. "Dekatnya pun bukan sekadar kulit ke kulit, melainkan dari jiwa ke 


\section{Adversity Quotient}

Dalam perjalanan menempuh studi atau karir, tahap demi tahap seseorang akan semakin maju. Tetapi rintangan dan kesulitan selalu ada. Adversity Quotient merupakan faktor yang dapat menentukan bagaimana, jadi atau tidaknya, serta sejauh mana sikap, kemampuan dan kinerja dapat terlaksana dengan baik. Menurut Stoltz, orang yang memiliki Adversity Quotient tinggi akan lebih mampu mewujudkan citacitanya dibandingkan orang yang Adversity Quotientnya lebih rendah. Untuk memberikan gambaran, Stoltz meminjam terminologi para pendaki gunung. Dalam hal ini, Stoltz membagi para pendaki gunung menjadi tiga bagian yaitu Quitter, Camper, dan Climber ${ }^{29}$ dengan ciri, deskripsi dan karakteristik sebagai berikut :

a. Quitters, yaitu orang yang langsung berhenti di awal pendakian. Mereka cenderung untuk selalu memilih jalan yang lebih datar dan lebih mudah. Mereka umumnya bekerja sekedar untuk hidup, semangat kerja yang minim, tidak, tidak berani mengambil resiko dan cenderung tidak kreatif. Umumnya tidak memiliki visi yang jelas serta berkomitmen rendah ketika menghadapi tantangan di hadapan. Disamping itu Quitter cenderung menghindari tantangan berat dan terampil dalam menggunakan kata-kata yang sifatnya membatasi, seperti "mustahil”, "ini Konyol”, "tidak mungkin" dan sebagainya.

jiwa" https://gaya.tempo.co/read/774751/7-pilar-mendidik-anak-menurut-psikologelly-risman diakses pada tanggal 8 Januari 2018.

${ }^{29}$ Paul G. Stoltz, Adversity Quotient, terj. T. Hermaya (Jakarta: PT. Grasindo, 2000), h. 18-19. Lihat juga Paul G.Stolzt dan Erik Weinhenmayer, judul Adversity AdvantageMengubah Masalah Menjadi Berkah, terj.Kusnandar (Jakarta: PT.Gramedia Pustaka Utama, 2008), h. XXV. Lihat juga Miarti Yoga, Adversity Quotient Agar Anak Tak Gampang Menyerah (Solo: Tinta Medina, 2016), h. 29-30.

Jurnal Ilmiah Al QALAM, Vol. 12, No. 2, Juli-Desember 2018 
b. Campers, yaitu orang yang berhenti dan tinggal di tengah pendakian. Mendaki secukupnya lalu berhenti kemudian mengakhiri pendakiannya. Umumnya setelah mencapai tingkat tertentu dari pendakiannya maka fokusnya berpaling untuk kemudian menikmati kenyamanan dari hasil pendakiannya. Maka banyak kesempatan untuk maju menjadi lepas karena fokus sudah tidak ada lagi pada pendakiannya. Sifatnya adalah satisficer atau merasa puas dengan hasil yang sudah dicapai. Akan tetapi camper ini lebih baik karena biasanya mereka berani melakukan pekerjaan yang berisiko, tetapi tetap mengambil resiko yang terukur dan aman. "ngapain capekcapek" atau "segini juga sudah cukup" adalah moto para Camper. Orang-orang ini sekurang-kurangnya sudah merasakan tantangan dan selangkah lebih maju dari para Quitter. Sayangnya banyak potensi diri yang tidak teraktualisasikan dan yang jelas pendakian itu sebenarnya belum selesai.

c. Climbers yaitu orang yang berhasil mencapai puncak pendakian. Mereka senantiasa terfokus pada usaha pendakian tanpa mengiraukan kemungkinan dan tidak akan pernah terkendala oleh hambatan yang dihadapinya. Mundur sejenak adalah proses alamiah dari pendakian dan mereka senantiasa mempertimbangkan dan mengevaluasi hasil pendakiannya untuk kemudian bergerak lagi maju hingga puncak pendakian tercapai. Orang tipe ini selamanya hidup selalu merasa tertantang untuk mendaki puncak yang lebih tinggi. Tidak peduli latar belakang, nasib atau keuntungan dia meneruskan pendakian. Dalam konteks ini, para Climber dianggap memiliki Adversity Quotient tinggi. Dengan kata lain Adversity Quotient membedakan antara para Climber, Camper dan Quitter. 
Paul G. Stoltz dan Erik Weihenmayer menjelaskan bahwa AQ terdiri atas empat dimensi yang disingkat dengan CORE (Control, Ownership, Reach, Endurance). ${ }^{30}$ Sebelumnya Stoltz mengatakan bahwa dimensi AQ terdiri dari Control, Origin, dan Ownership, Reach, dan Endurance (CO2RE). ${ }^{31}$ Dalam penelitiannya Stoltz mengatakan bahwa dimensi Origin dan Ownership saling berkaitan.

1) $\mathrm{C}=$ Control (Pengendalian) $/$ Mengendalikan diri saat menghadapi masalah.

2) $\mathrm{O}=$ Ownership (Penguasaan Diri) / sejauh apa dia bisa mencari solusi dari setiap permasalahan.

3) $\mathrm{R}=$ Reach (Jangkauan) / Bagaimana agar masalah yang ada tidak menyentuh bagian lain dalam aktivitas kegiatannya

4) $\mathrm{E}=$ Endurance $($ Daya Tahan) / bertahan terhadap masalah yang terjadi.

Pendidikan Adversity Quotient dalam Islam diantaranya adalah pendidikan sabar, pendidikan optimis dan pantang menyerah, pendidikan berjiwa besar dan pendidikan jihad. Pendidikan sabar selaras dengan dimensi control pada Adversity Quotient, pendidikan optimis dan pantang menyerah selaras dengan dimensi ownership pada Adversity Quotient, pendidikan berjiwa besar selaras dengan dimensi reach pada Adversity Quotient dan pendidikan jihad selaras dengan dimensi endurance pada Adversity Quotient. Nilai-nilai pendidikan tersebut sangat diperlukan dalam pendidikan Islam, guna menghasilkan generasigenerasi muslim yang cinta akan perjuangan, pantang menyerah dengan segala hambatan, berani menghadapi tantangan, kebal terhadap

\footnotetext{
${ }^{30}$ Paul G.Stolzt dan Erik Weinhenmayer, Adversity Advantage..., h.xxviii.

${ }^{31}$ Paul G. Stoltz, Adversity Quotient...,h.140. lihat juga Paul. G. Stolt dan Erik Weihenmayer, The Adversity Advantage ..., h. 100 - 109.
}

Jurnal Ilmiah Al QALAM, Vol. 12, No. 2, Juli-Desember 2018 
kesulitan dan semangat dalam menjalani kehidupan khususnya dunia pendidikan. ${ }^{32}$ Konversi agak berbeda dipaparkan oleh Husin, Sabar adalah bentuk lain dari dimensi Control. Ikhtiar dan optimis adalah bentuk lain dari Ownership yang diajarkan dalam teori Adversity Quotient. Husnu al-zhan, ridha dan ikhlas adalah penjabaran lain dari reach, Himmah, khauf dan raja' yang merupakan bentuk dari dimensi Endurance. ${ }^{33}$

\section{E. Fathering Adversity Quotient}

Dalam sebuah seminar parenting, Ustadz Adriano Rusfi, M.Psi mengajukan pertanyaan terkait siapa yang paling bertanggung jawab dalam hal pendidikan anak. Beliau menjawab bahwa Ayah adalah orang yang paling bertanggung jawab dalam hal pendidikan anak. Dalam Alquāan Allah kisahkan kisah-kisah bagaimana mendidik anak, dan semuanya dilakukan oleh Ayah. Ada kisah Lukman yang mendidik anak dan keluarganya, kisah Ibrahim dengan putra kesayangannya, ada kisah Imron, Zakaria dan Yakub yang berperan mendidik anak-anaknya. Begitu pentingnya peran Ayah dalam mendidik anak hingga tujuh belas ayat dalam Alqurānyang menjelaskan peran orang tua dalam mendidik anak, empat belas ayat di antaranya dilakukan oleh sosok seorang Ayah, dua ayat dilakukan oleh sang Ibu dan satu ayat dilakukan oleh keduanya.

Kegagalan pendidikan anak lantaran disebabkan karena ketidakterlibatan seorang Ayah dalam pendidikan anak di keluarga. Seorang Ayah hanya fokus mencari nafkah dan berlepas diri dalam hal pendidikan anaknya dan mendelegasikan kepada sang Ibu. Kegagalan itu

\footnotetext{
${ }^{32}$ Muh Haris Zubaidillah, "Pendidikan Adversity Quotient Dalam Konsep Islam" Addabana 1, no. 2 (2018), h. 19.

${ }^{33}$ Husin, 'Adversity Quotient Pada Cerita Edukatif Surah Yūsūf (Dalam Perspektif Pendidikan Islam)" Al Qalam 10, no. 2 (2016), h. 169.
}

Jurnal Ilmiah Al QALAM, Vol. 12, No. 2, Juli-Desember 2018 
tampak terlihat pada keluarga-keluarga di sekitar kita, di mana anak-anak lebih cepat mencapai masa balighnya, namun masa aqilnya terlambat jauh. Kasus-kasus pembunuhan, pemerkosaan dan narkoba yang dilakukan oleh anak-anak terjadi lantaran masa baligh jauh lebih cepat dialami anak dari masa aqilnya. Dalam Islam, masa aqil dan baligh harus hadir bersamaan pada anak-anak.

Ada beberapa perbedaan apa itu aqil dan baligh:

1. Aqil berarti dewasa dalam mental, baligh dewasa dalam hal fisik;

2. Aqil karena pengaruh pendidikan sementara baligh disebabkan pengaruh nutrisi makanan;

3. Aqil terkait perkembangan otak, sedangkan baligh terkait perkembangan nafsu;

4. Aqil terkait fungsi tanggung jawab, sedangkan baligh terkait fungsi reproduksi;

5. Aqil berarti kemandirian dan tanggung jawab, sedangkan baligh berarti life and death instinct.

Bukan sosok Ibu yang akan diminta pertanggungjawabannya di akhirat kelak, namun sosok Ayahlah yang harus mempertanggungjawabkan anak-anaknya. Tidak mengherankan bila kelak ada seorang Ayah yang ahli ibadah, namun ia harus terseret ke neraka lantaran protes anak-anaknya yang tidak pernah diajarkan bagaimana menjadi anak yang sholeh dan sholehah.

Ada beberapa peran Ayah yang tak bisa digantikan oleh sosok Ibu:

1. Man of vision and mission;

2. Penanggung Jawab;

3. Konsultan pendidikan; 
4. Mendidik aqidah dan keimanan;

5. Sang ego dan individualitas;

6. Membangun sistem berpikir;

7. Supplier maskulinitas;

8. The King of Tega.

Mind set bahwa mendidik anak adalah tanggung jawab ibu harus disingkirkan jauh-jauh. Seorang Ayah harus mendominasi dalam hal mendidik anak dalam keluarga. Semakin baik peran para Ayah dalam mendidik anak di keluarga, diharapkan mampu mendorong terciptanya peradaban baru dengan generasi yang sholeh secara individu dan sosial. ${ }^{34}$

Terkait tema utama dalam penelitian ini yaitu Fathering Adversity Management, yaitu bagaimana cara Ayah memberikan pelajaran tentang mengatasi segala permasalahan dalam kehidupan dapat kita pelajari dari tokoh-tokoh ayah dalam Alqurān. salah satunya adalah Nabi Ya'qūb as. Beliau adalah tokoh ayah yang yang terabadikan dalam Alqurān surah Yūsūf dan menjadi ibrah bagi orang tua dalam mendidikan anak khususnya bagaimana cara Ayah mengajarkan tentang menghadapi kehidupan kepada anak-anaknya.

Pengasuhan yang diajarkan oleh Nabi Ya'qūb as. tercermin dalam awal surah Yūsūf / 12:4-5. Kedua ayat tersebut mengandung makna FAM (Fathering Adversity Management) yaitu dengan menyuruh Nabi Yūsūf as. untuk menyembunyikan rahasia besar tersebut Nabi Ya'qūb as. bukan hanya ingin melindungi perasaan anak-anaknya yang lain, akan tetapi juga mengajarkan kepada Nabi Yūsūf as. tentang kesabaran (dimensi control) dan menahan diri untuk tidak membuka

\footnotetext{
${ }^{34}$ Diakses melalui http://sippfm.com/peran-ayah-dalam-pendidikan-anak/ tanggal 18 September 2018.
}

Jurnal Ilmiah Al QALAM, Vol. 12, No. 2, Juli-Desember 2018 
rahasia besar yang Allah swt. anugerahkan kepadanya (dimensi endurance) karena ada kekhawatiran dari perbuatan makar yang nantinya akan dilakukan oleh saudara-saudaranya.

Surah Yūsūf / 12:16-18 menunjukkan FAM yang sangat luar biasa untuk diamalkan oleh orang tua zaman sekarang. Pada kedua ayat tersebut secara tersirat Nabi Ya'qu.b menunjukkan bahwa beliau sudah mengetahui apa yang telah dilakukan oleh saudara-saudaranya Nabi Yūsūf as., akan tetapi beliau menegur dengan lembut namun tegas seraya mengembalikan setiap musibah yang terjadi adalah atas kehendak Allah swt. Pola pengasuhan seperti ini adalah contoh pengasuhan yang baik apabila anak telah melakukan kesalahan seraya tetap mengarahkan anak kembali ke jalan yang benar. Nilai kesabaran dari Nabi Ya'qūb merupakan contoh dimensi control dalam Adversity Quotient.Kedua ayat ini kemudian ditegaskan kembali dalam surah Yūsūf / 12:83 yang juga mengajarkan tentang kesabaran, tidak putus asa dan memahami bahwa setiap permasalahan pasti ada jalan keluarnya.

Ayat berikutnya dalam surah Yūsūf / 12:84 menunjukkan bagaimana Nabi Ya'qūb as. menahan amarahnya terhadap apa yang telah dilakukan anak-anaknya. Pola pengasuhan yang mengajarkan tentang Fathering Adversity Management sangat jelas terasa. Hal ini juga mengajarkan kepada siapapun bahwa kemarahan orang tua (Ayah) kepada anaknya tidak serta merta menghilangkan sikap kasih ayah seorang Ayah kepada anak-anaknya.

Fathering Adversity Management yang diajarkan oleh Nabi Ya'qūb as. dapat kita lihat pada surah Yūsūf / 12:86. Ayat tersebut mengajarkan kepada orangtua (Ayah) agar bisa menanamkan keyakinan kepada anak-anaknya bahwa seberat apapun kesusahan dan kesedihan 
yang sedang dialami jangan sampai membuat diri terpuruk dan menyerah terhadap keadaan. Keyakinan untuk dapat merubah keadaan kepada yang lebih baik dan selalu berjuang untuk meraih segala kesuksesan yang dicita-citakan harus selalu ditanamkan dan dipupuk sehingga menjadi tabiat yang tumbuh subur dalam diri.

Ayat berikutnya pada surah Yūsūf / 12:87 juga mengajarkan bahwa seberat apapun ujian selalu berusaha untuk mencari jalan keluarnya disertai harapan bahwa pertolongan Allah selalu ada untuk orang-orang yang berusaha. Nabi Ya'qūb juga menyuruh anak-anaknya dengan perintah Tahassa yang berarti mencari Yūsuf dengan segala daya dan kemampuan yang ada. kata Tahassa berbeda dengan kata tajassus yang hanya menggunakan indera mata dan telinga untuk mencari Yūsuf. Jelas sekali Nabi Ya'qūb mengajarkan kepada anak-anaknya untuk selalu dan berusaha pantang menyerah dalam melakukan sesuatu.

\section{F. Simpulan}

Menjadi ayah pada zaman sekarang bukanlah perkara mudah. Mereka tidak hanya dituntut untuk memahami kondisi psikologis anak melainkan juga harus memahami dinamika sosial yang ada di sekitarnya. Ayah yang baik belum tentu benar. Demikan pula sebaliknya, ayah yang benar belum tentu baik. Keduanya harus beriringan dalam pelaksanaannya. Ayah yang baik adalah ayah yang bisa menempatkan diri sesuai dengan usia dan kejiwaan anak. Ketika orang tua mengerti bagaimana memperlakukan anak sesuai dengan usia dan kejiawaan anak tentu akan mudah mengantarkan anak ke jalan yang benar.

Fathering Adversity Management yang peneliti tawarkan adalah pengembangan konsep Adversity Quotient yang dikemukakan oleh Paul G. Stoltz. Teori FAM yang peneliti tawarkan didasarkan atas kajian 
peneliti terhadap ayat-ayat Alqurān yang mengandung dialog antara Ayah dan anak sehingga bisa menjadi sebuah kajian baru yang menarik untuk digali dan dikembangkan dengan pendekatan pendidikan Islam.

\section{G. Saran-Saran}

Hasil penelitian ini masih merupakan kajian awal dari apa yang nantinya peneliti akan lakukan. Langkah selanjutnya yang akan peneliti lakukan adalah menggali lebih dalam terhadap ayatayat dialog antara Ayah dan anak dalam Alqurān. Hasil penelitian ini pun tidak menutup kemungkinan ditindaklanjuti oleh peneliti lain berdasarkan kompetensi masing-masing peneliti. Hal ini dimaksudkan agar teori FAM bisa didekati dengan berbagai disiplin ilmu seperti ilmu Sosiologi, Antropologi, Psikologi maupun disiplin ilmu lainnya. 


\section{Daftar Pustaka}

'Ik, Syekh Khalid bin Abdurrahman. Prophetic Parenting, terj. Dwi dan Aguk. Yogyakarta: Laksana, 2017.

'Ulwan, Abdullah Nashih. Pendidikan Anak Dalam Islam, terj. Arif Rahman Hakim. Jawa Tengah: Insan Kamil Solo, 2017.

Astuti, Vera dan Achmad Mujab Masykur. "Pengalaman Keterlibatan Ayah Dalam Pengasuhan Anak (Studi Kualitatif Fenomenologis), Jurnal Empati Volume 4, no. 2 (2015).

Buseri, Kamerani. Pendidikan Keluarga Dalam Islam dan Gagasan Implementasinya. Banjarmasin: Lantin G, 2010.

G. Stoltz, Paul. Adversity Quotient, terj. T. Hermaya. Jakarta: PT. Grasindo, 2000.

G.Stolzt, Paul dan Erik Weinhenmayer. Adversity Advantage Mengubah Masalah Menjadi Berkah, terj.Kusnandar. Jakarta: PT.Gramedia Pustaka Utama, 2008.

http://sippfm.com/peran-ayah-dalam-pendidikan-anak

http://www.kpai.go.id/files/2013/09/uu-nomor-35-tahun-2014-tentangperubahan-uu-pa.pdf

https://gaya.tempo.co/read/774751/7-pilar-mendidik-anak-menurutpsikolog-elly-risman

https://t-anderson.squarespace.com/s/ImportantRoleofFathers

Husin, 'Adversity Quotient Pada Cerita Edukatif Surah Yūsūf (Dalam Perspektif Pendidikan Islam)" Al Qalam 10, no. 2 (2016)

Kementerian Agama. Al-Quran Tikrar. Bandung: Sygma Creative, 2014.

M. Hanafi, Muchlis dkk. Biografi Lima Imam Madzhab Imam Ahmad Imam Besar dan teladan Bagi Umat Pendiri Madzhab Hanbali. Tangerang: Lentera Hati, 2013.

- Biografi Lima Imam Madzhab Imam Mālik Penapak Atsār dan Tradisi Ahli Madinah Pendiri Madzhab Maliki. Tangerang: Lentera Hati, 2013.

- Biografi Lima Imam Madzhab Imam Syāfi'i Sang Penopang Hadits dan Penyusun Ushul Fiqh Pendiri Madzhab Syafi'i. Tangerang: Lentera Hati, 2013. 
Maharani, Putri dan Budi Andayani. "Hubungan Antara Dukungan Sosial Ayah Dengan Penyesuaian Sosial Pada Remaja Laki-Laki "Jurnal Psikologi UGM), vol.xxx no.1 (2003)

Muthairi, Sarah binti Halil. Hiwār al-Abā ma'al Abnā Fil Qurānil Karīm Wa Tathbiquàtuhu at-Tarbawiyah. Tesis tidak diterbitkan, Universitas Ummul Qura, Mekkah, 2008.

Rosenberg, Jeffrey and W. Bradford Wilcox. The Imprortance of Fathers in the Healthy Development of Children. tt : tp, 2006.

Salam, Lubis. Menuju Keluarga Sakinah Mawaddah Wa Rahman . Surabaya: Terbit Terang, tt.

Setiawan, Agus. Konsep Pendidikan Tauhid dalam Keluarga Perspektif Pendidikan Islam, EDUCASIA, Vol. 2 No. 1, 2017.

Scott, William and Amy De La Hunt. The Important Role of Fathers in the Lives of Young Children. st.Louis : Parents as Teachers, 2011.

Shadik, Jenifer. Fathering Child Maltreatment : A Grounded Theory Study. Richmond: Virginia Commonwealth University, 2014.

Yoga, Miarti. Adversity Quotient Agar Anak Tak Gampang Menyerah. Solo: Tinta Medina, 2016.

Zamakhsyari, Abu al-Qāsim Mahmūd ibn Umar' ${ }^{-}$. Al-Kasysyaf 'an Haqa'iq at-Tanzīl wa 'Uyün al-Aqāwil Fì Wujūh at-Ta'wīli, juz 1. Mesir: Musthafa al-Bāb al-Halabȳ wa Aulāduh, tt.

Zubaidillah, Muh. Haris. "PendidikanAdversity Quotient Dalam Konsep Islam" Addabana 1, no. 2 (2018)

Jurnal Ilmiah Al QALAM, Vol. 12, No. 2, Juli-Desember 2018 
Husin: Fathering Adversity Management

Jurnal Ilmiah Al QALAM, Vol. 12, No. 2, Juli-Desember 2018 24 